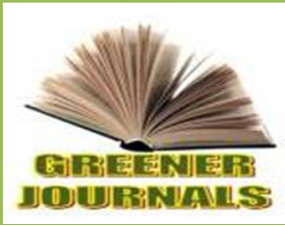

\title{
Trypanosomiaisis in Non Migratory Cattle in Suburban Kaduna
}

\section{Dauda H., Abubakar S., Muhammad A.A., Jarmai K.Y., Uzoigwe L., Allen D.O., Ahmed A.A., Ngamdu A.S., Jega Z., *Wayo B. \& Kalejaiye J.O.}

\author{
Trypanosomiasis Research Department, Nigeria Institute for Trypanosomiasis Research, \\ Kaduna, Nigeria.
}

\section{ARTICLE INFO}

Article No.: 082917113

DOI: 10.15580/GJAS.2017.7.082917113

Submitted: $29 / 08 / 2017$

Accepted: 04/09/2017

Published: 15/09/2017

${ }^{*}$ Corresponding Author

Wayo $B$.

E-mail: duchiwayo@gmail.com

\section{Keywords:}

Trypanosomiasis, cattle, migration, reservoir, suburban, Kaduna
African trypanosomiasis is a disease complex, prevalent in sub-Saharan Africa, influencing both public health and agricultural development. The disease is also becoming increasingly prevalent beyond its traditionally defined realm. Studies have shown that migration increases the risk of cattle being infected with trypanosomes and that Trypanosoma brucei populations in cattle (and other domestic animals) could serve as reservoirs for the human infection. This study involves an investigation into the prevalence of Trypanosomiasis among cattle herds kept extensively but do not seasonally migrate. It was conducted in Guguwa- Rigasa, Igabi local government area of Kaduna State, North-West Nigeria.A total of 157 cattle, sheep, goats and dogs were sampled from three herds.Parasitological examination was carried out using the Standard Trypanosome Detection Method. Trypanosome species were identified based on their motility using the Buffy coat method and morphological features from Giemsa stained films. A total of $25(15.92 \%)$ animals were found to be positive with Trypanosoma congolense and $T$. brucei. It can be concluded that animal trypanosomiasis is prevalent in the area. However, further and more sensitive studies need to be carried out to bring more clarity on the parasite species, vectors and overall epidemiology of the disease. 


\section{INTRODUCTION}

African trypanosomiasis is a disease complex, prevalent in sub-Saharan Africa, with enormous effects on the lives of man and his animals in the region. It influences both public health and agricultural development (llemobade 2009). It remains one of the biggest infectious disease constraints to livestock production in the region where estimates of $5-10 \%$ increase in GDP and almost $\$ 5$ billion dollars savings (from annual losses) are projected once the disease is controlled (Auty et al., 2015; llemobade 2009).

African animal trypanosomiasis is also becoming increasingly prevalent beyond its traditionally defined realm with studies showing that Trypanosoma brucei populations in cattle (and other domestic animals) could serve as reservoirs for the human infective subspecies of trypanosomes (Welburn et al., 2001; Njiokou et al., 2010; Karshima et al., 2012; Hamil et al., 2013; Auty et al., 2015). The movement of cattle is also being implicated in the spread and seeding of human disease outbreaks caused by this pathogen. Strong links have also been shown between human infection and agricultural activities (Robays et al., 2004, Auty et al., 2015). Studies have also shown that migration increases the risk of cattle being infected with trypanosomes (Majekodunmi et al., 2013, Samdi et al., 2010).

Our study involves an investigation into the prevalence of Trypanosomiasis among cattle herders who keep their animals extensively but are not known for the typical seasonal migration among fulani cattle rearers.

\section{MATERIALS AND METHODS}

Study area: The study was conducted in GuguwaRigasa, Igabi local government area of Kaduna State, North-West Nigeria in the month of May 2015.Rigasa is part of Kaduna metropolis. Kaduna State is located on latitude $10^{\circ} \mathrm{N}$, longitude $7^{\circ} \mathrm{E}$ and altitude $616 \mathrm{~m}$ (highest point) above sea level. Mean annual rainfall is between $880-1380 \mathrm{~mm}$. The area lies within the sub - humid zone which is characterised by dry season period from November to April, and a rainy season from May to October .The vegetation consist of the typical northern guinea savannah woodland.
Sampling was carried out at two points in Guguwa. They are; N 10 30'53" E $7^{\circ} 19^{\prime} 21.3^{\prime \prime}$ and N $10^{\circ} 33^{\prime} 10.7^{\prime \prime}$ E 70 19' 17.6" Elevation 641m.

Sampling and Diagnosis: A total of 157 animals were sampled. These include 95 cattle, 51 goats, 5 sheep and 6 dogs sampled from three herds. These animals are housed and sometimes herded by the Fulani herdsmen. About $3 \mathrm{~mL}$ of blood was drawn from jugular vein using a hypodermic needle and transferred into Ethylene Diamine Tetra-acetetic Acid ( EDTA) sample bottle. Parasitological examination was carried out using the Standard Trypanosome Detection Method i.e. haematocrit centrifugationtechnique, HCT (Woo, 1971); Buffy Coat Method, BCM (Murray et al., 1977) as well as Giemsa stained thick and thick films. The packed cell volume (PCV) of each animal was also determined, while trypanosome species were identified based on their motility using BCM and morphological features from Giemsa stained films.

Statistical analysis:The data obtained from this study were analysed using student's t-test in the SPSS software. A p-value of $<0.05$ or less was considered significant.

\section{RESULTS}

A summary of the results can be seen in the table below.

A total of $25(15.92 \%)$ animals were found to be positive with Trypanosoma congolense and $T$. brucei. The average PCV among cattle was 26.75. The average PCV among infected cattle (25.23) appeared lower than those uninfected (31.34). The values were statistically significant $(p<0.05)$. Clinical signs were consistent with trypanosomiasis (eg. rough coat, lacrimation, emaciation) were also observed on the herds.

The average PCV in goats was found to be 24.34. The average PCV of the infected goats (21.75) appeared lower than that of the uninfected (25.00). The values were however statistically insignificant $(p>0.05)$. Animals did not exhibit any clinical signs attributable to trypanosomiasis.

No parasites were observed in the sheep or dogs sampled.

Table 1: Summary of Results

\begin{tabular}{|l|l|l|l|l|}
\hline Animal & Number Sampled & $\begin{array}{l}\text { Number of } \\
\text { Positive }\end{array}$ & $\begin{array}{l}\text { Number } \\
\text { Negative }\end{array}$ & $\begin{array}{l}\text { Trypanosome } \\
\text { Species }\end{array}$ \\
\hline Cattle & 13 & 82 & $\begin{array}{l}\text { Trypanosoma } \\
\text { congolense } \\
\text { Trypanosoma } \\
\text { brucei (3) }\end{array}$ \\
\hline Goat & 95 & $10)$ & $\begin{array}{l}\text { T. congolense (11) } \\
\text { T. brucei (1) }\end{array}$ \\
\hline Sheep & 51 & 12 & 39 & - \\
\hline Dog & 5 & 0 & 5 & - \\
\hline Total & 6 & 0 & 6 & \\
\hline
\end{tabular}




\section{DISCUSSION AND CONCLUSION}

A prevalence report of $15.92 \%$ is a cause for concern especially when one considers that these animals are non-migratory and their settlement is on the fringe of a highly populated suburban area. An area where farming and human settlements are presentgreatly reduces vector (tsetse fly) population(thereby the possibility of infection) due to thefragmentation of their habitat (Ducheyne et al.,2009).

Treks have been demonstrated to significantly increase the risk of contracting trypanosome infections (Majekodunmi et al., 2013). Although there was no investigation into the presence of tsetse in the area, it is plausible that infections were picked up from riverine tsetse species (eg Glossina tachinoides) that have retreated to the banks of streams and ponds which these cattle are taken to drink during grazing. These species have also been observed of recent to exhibit peridomestic behaviour as a means of adaptation to their changing habitat (Dede et al., 2005).

Of concern is also the possibility of these animals harbouring human infective trypanosomes (Auty et al., 2015, Karshima et al., 2012). Though there are no studies yet carried out to shed more light on this in the area. Of interest also were the infected goats that showed no visible signs of illness. This may further validate their trypanotolerant trait.

Trypanosoma congolense was also observed to be the most prevalent trypanosome species in the study further proving its dominance as the most widespread species causing cattle trypanosomiasis (Auty et al., 2015).

It can be concluded that animal trypanosomiasis is prevalent in the area. Further and more sensitive studies need to be carried out to bring more clarity on the parasite species, vectors and overall epidemiology of the disease.

\section{REFERENCES}

Auty H., S.J. Torr, T. Michoel, S. Jayaraman \& L.J. Morrison (2015).Cattle trypanosomosis: the diversity of trypanosomes and implications for disease epidemiology and control. Rev. Sci. Tech. Off. Int. Epiz., 2015, 34 (2), 587-598

Dede P.M. I. Halid G.A. Omoogun N.R. Uzoigwe C.I. Njoku A.D. Daniel A.J. Dadah (2005) Current Tsetse and TrypanosomosisSituation on Jos Plateau, Nigeria.Epizootiological Factorsthat May Enhance
DiseaseTransmission and Spread Revue Élev. Méd. vét. Pays trop., 2005, 58 (1-2): 31-35

Ducheyne E., Mweempwa C., De Pus C., Vernieuwe H., De Deken R., Hendrickx G. and Van Den Bossche P. (2009). The impact of habitat fragmentation on tsetse abundance on the plateau of eastern Zambia. Preventive Veterinary Medicine (2009). Sep. 1; 91(1): 11-18.

Hamil L.C., Kaare T.M., Welburn S.C. and Picozzi K. (2013).Domestic pigs as potential reservoirs of human and animal trypanosomiasis in Norther Tanzania. Parasites \& Vectors November 2013. 6:32.

Ilemobade A.A. (2009). Tsetse and trypanosomosis in Africa: The challenges, the opportunities. Onderstepoort Journal of Veterinary Research, 76:35-40 (2009)

Karshima N. S., Ajogi I., Lawal A. I., Mohammed G. and Okubanjo O. O. (2012). Detection of Trypanosoma Brucei Gambiense Specific Li Tat 1.3 Antibodies in Humans and Cattle in Taraba State, North-Eastern Nigeria. J Vet Adv 2012, 2(12): 580-585

Majekodunmi A.O., Fajinmi A., Dongkum C., Picozzi K., Thrusfield M.V. and Welburn S.C. (2013). A longitudinal survey of African animal trypanosomiasis in domestic cattle on the Jos Plateau, Nigeria: prevalence, distribution and risk factors. Parasites \& Vectors 2013, 6:239 http://www.parasitesandvectors.com/content/6/1/239

Murray M., P.K. Murray and W.I.M. Mclntyre (1977). An improved Parasitological technique for the diagnosis of African Trypanosomiasis. Transactions of the Royal Society of Tropical Medicine and Hygiene. 71; 325-326.

Njiokou F., Nimpaye H., Simo G., Njitchouang G.R., Asonganyi T., Cuny G. and Herder S. (2010). Domestic animals as potential reservoir hosts of Trypanosomabruceigambiense in sleeping sickness foci in Cameroon.Parasite 2010 Mar;17(1):61-6.

Robays J., A. Ebeja Kadima, P. Lutumba, C. Miaka mia Bilenge, V. Kande Betu Ku Mesu, R. De Deken, J. Makabuza, M. Deguerry, P. Van der Stuyft and M. Boelaert (2004). Human African trypanosomiasis amongst urban residents in Kinshasa: a case-control study. Tropical Medicine and International Health volume 9 no 8 pp 869875 august 2004

Samdi S.M., J.N. Abenga, A. Attahir, B. Wayo and H.M. Sumayin (2010). Constraints in the control of Trypanosomiasis: The prevailing factors in Kurmin Kaduna. International Journal of Animal and Veterinary Advances. 2;31-36.

Welburn S.C., Picozzi K., Fevre E.M., Coleman P.G., Odiit M., Carrington M. and Maudlin I. (2001). Identification of human-infective trypanosomes in animal reservoirs of sleeping sickness in Uganda by means of serumresistance-associated (SRA) gene. Lancet 2001 Dec 15;358(9298):2017-9.

Woo P.T.K. (1971). Evaluation of Hematocrit centrifuge and other techniques for field diagnosis of Trypanosomiasis and Filariasis. Acta Tropica 28;298-303. 